University of Nebraska - Lincoln DigitalCommons@University of Nebraska - Lincoln

USGS Staff -- Published Research

US Geological Survey

1981

\title{
A Pleistocene Sand Sea on the Alaskan Arctic Coastal Plain
}

\author{
L. David Carter \\ U.S. Geological Survey, Menlo Park, CA
}

Follow this and additional works at: http://digitalcommons.unl.edu/usgsstaffpub

Part of the Geology Commons, Oceanography and Atmospheric Sciences and Meteorology Commons, Other Earth Sciences Commons, and the Other Environmental Sciences Commons

Carter, L. David, "A Pleistocene Sand Sea on the Alaskan Arctic Coastal Plain" (1981). USGS Staff -- Published Research. 924. http://digitalcommons.unl.edu/usgsstaffpub/924

This Article is brought to you for free and open access by the US Geological Survey at DigitalCommons@University of Nebraska - Lincoln. It has been accepted for inclusion in USGS Staff -- Published Research by an authorized administrator of DigitalCommons@University of Nebraska - Lincoln. 


\section{Reports}

\section{A Pleistocene Sand Sea on the Alaskan Arctic Coastal Plain}

Abstract. A ridge and thermokarst-basin landscape that is strikingly portrayed in Landsat winter imagery consists of large Pleistocene dunes that have been modified by younger eolian activity and thermokarst processes. This is the most extensive area of large stabilized dunes yet reported in the North American Arctic; the landscape is of particular interest because it has been proposed as a first-order analog for martian fretted terrain. Recognition of the large dunes permits a new interpretation for linear and curvilinear trends visible in Landsat summer imagery.

Large stabilized dunes of a Pleistocene sand sea covering more than $7000 \mathrm{~km}^{2}$ of the Alaskan Arctic Coastal Plain (Fig. la) have been identified by analysis of Landsat imagery combined with ground observations. Landsat winter imagery (Fig. 2a) reveals symmetrical, parallel to subparallel ridges as long as $20 \mathrm{~km}$ and as wide as $1 \mathrm{~km}$ trending ENE-WSW to NE-SW. Field studies show that the cores of the ridges are composed of eolian sand that in places is more than $20 \mathrm{~m}$ thick. Bedding attitudes in the sand are compatible with net sand transport parallel to rather than across the ridge axes, and the ridges are interpreted as linear dunes (l). Because the predominant ridge orientations roughly parallel the modern prevailing winds, the dunes may have formed under a wind regime similar to the present one. These large dunes are now obscured by a thin cover of younger eolian sand that includes small, stabilized longitudinal and parabolic dunes generally less than $1 \mathrm{~km}$ long (2). In addition, the large dunes have been extensively modified by thermokarst processes, making them difficult to detect on the ground or from aircraft. The younger eolian sand extends beyond the large dunes and coincides with the area of small longitudinal and parabolic dunes described by Black (2). In this report the term sand sea refers only to the large dunes of older eolian sand.

The subdued but distinctive ridge and thermokarst-basin landscape that now characterizes the area of large dunes was identified in the Landsat winter scene in Fig. 2a by Gatto and Anderson (3), who proposed it as a first-order analog for martian fretted terrain. However, they attributed the origin of the landscape to SCIENCE, VOL. 211, 23 JANUARY 1981 the development of thermokarst basins under the influence of bedrock structural control. Alignment of the thermokarst basins and intervening ridges was thought to parallel regional structural trends inferred from geophysical data and Landsat summer imagery (4), and the perennially frozen sand blanketing the area was thought to be dominantly

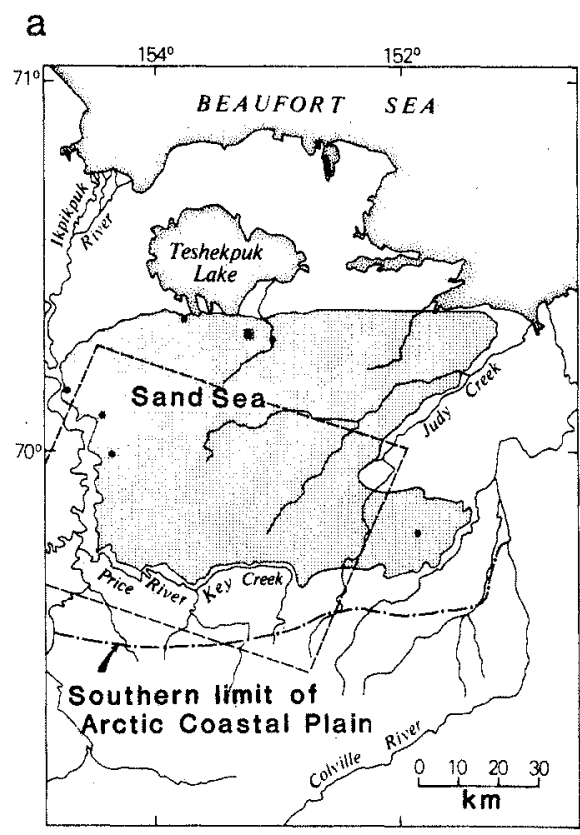

b

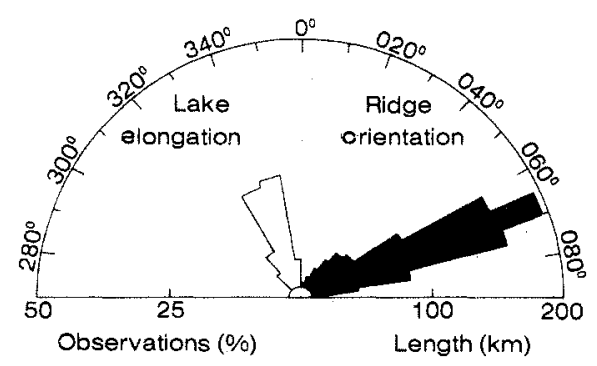

0036-8075/81/0123-0381\$00.50/0 Copyright (C) 1981 AAAS marine sand of the Quaternary Gubik Formation (5), with only the upper part reworked into the small longitudinal and parabolic dunes (2).

The relief in the ridge and thermokarst-basin landscape is sharply portrayed in the Landsat winter scene (Fig. 2a) because the image was obtained under conditions of low sun angle and apparently uniform snow cover. The low sun angle accentuated the long, broad ridges, which are difficult to discern in other Landsat images and topographic maps of this area. The small longitudinal and parabolic dunes are not visible. Because of the ice and snow, the numerous thaw lakes that dominate Landsat summer scenes are less obvious and thus do not interfere with a visual assessment of the ridge patterns. Thaw lake basins, however, are well defined.

Examination of Landsat winter imagery of adjacent areas shows that the ridge and thermokarst-basin terrain extends eastward from the Ikpikpuk River for as much as $105 \mathrm{~km}$ and northward from Price River for $77 \mathrm{~km}$, an area of roughly $7180 \mathrm{~km}^{2}$ (Fig. 1a). Topographic maps (6) show that the ridges are as high as $30 \mathrm{~m}$ and that the ridge and thermokarst-basin terrain forms a topograph-

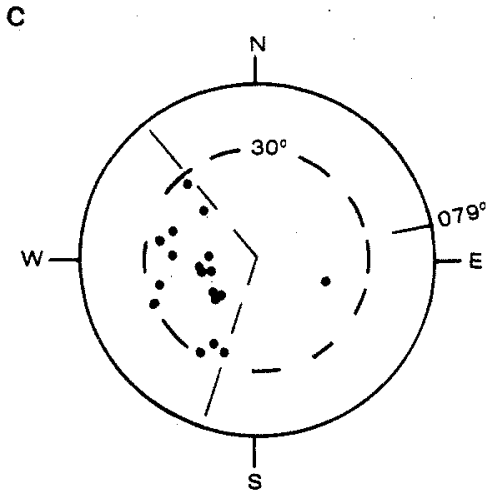

Fig. 1. (a) Map showing the extent of the Pleistocene sand sea. The Colville River is the eastern boundary of the National Petroleum Reserve in Alaska. Dashed lines indicate the approximate area of the image in Fig. 2a. The small square below Teshekpuk Lake shows the location of Fig. 2b. Circles mark the sites at which bedding attitudes in (c) were measured. (b) Polar histogram showing (i) total ridge length for ridges within each $5^{\circ}$ increment of orientation (shaded) and (ii) orientation of elongate axes (unshaded) of thermokarst lakes for that part of the $\mathrm{L}_{4}$ lake unit of Sellmann et al. (10) in the Teshekpuk quadrangle, plotted as a percentage of 325 observations. (c) Stereographic projection of dip measurements in 18 sets of cross-strata. Azimuth of dot represents dip direction; distance from center indicates degree of dip. 


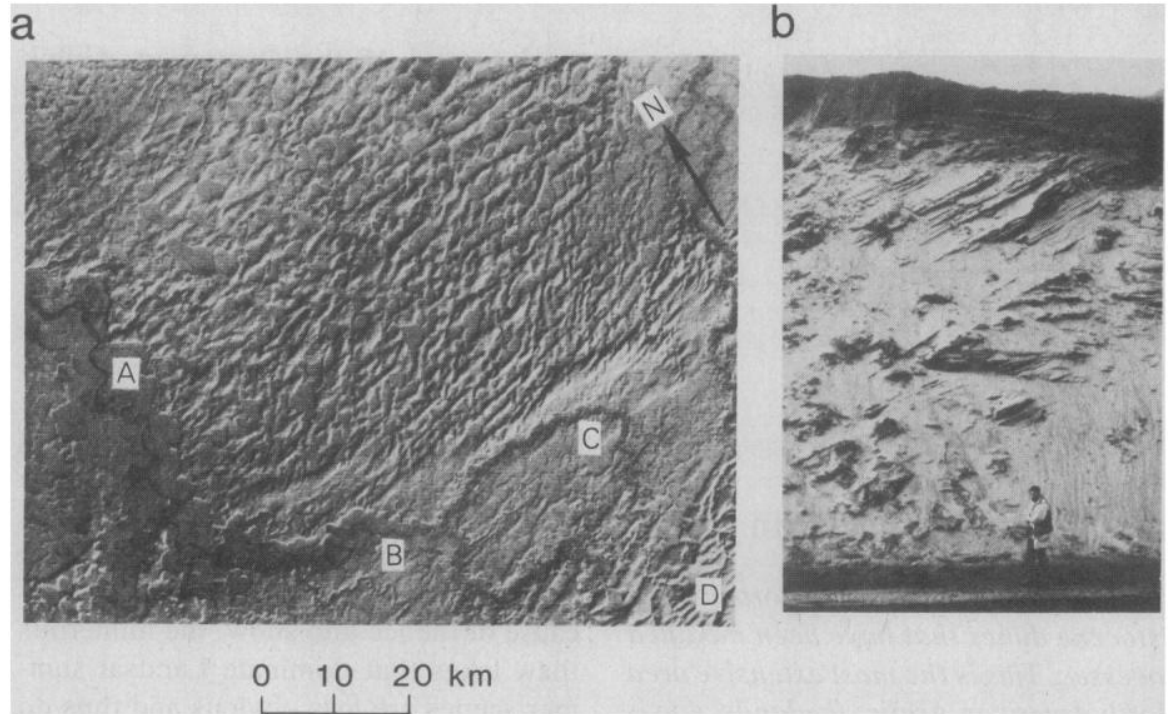

Fig. 2. (a) Portion of a Landsat-1 multispectral scanner, band 7, enhanced image (ID 1237 21353) of the Arctic Coastal Plain of Alaska ( $A$, Ikpikpuk River; $B$, Price River; $C$, Key Creek; and $D$, Arctic Foothills). If the terrain is perceived as plateaus and valleys, rotate the image $180^{\circ}$ to view as ridges and basins. Geometric corrections and a linear contrast stretch were carried out by the Image Processing Laboratory of the Jet Propulsion Laboratory for the U.S. Army Corps of Engineers Cold Regions Research and Engineering Laboratory (3). (b) Large-scale, high-angle cross-stratification in the northern part of the sand sea. The man is about $1.7 \mathrm{~m}$ tall.

ic high that is as much as $50 \mathrm{~m}$ higher than adjacent terrain. Price River and Key Creek have been deflected westward at the southern margin of the topographic high.

A map of the ridges was made from the image in Fig. 2a and the orientation and length were measured for each of the 302 mapped ridges. For each $5^{\circ}$ increment, beginning at $0^{\circ}$, the total ridge length was computed for ridges with orientations within that increment. Figure 1b shows the summations for each $5^{\circ}$ of azimuth. The total length of the mapped ridges was $1018 \mathrm{~km}, 66$ percent of which was oriented between $056^{\circ}$ and $080^{\circ}$. The dominant ridge trend is between $066^{\circ}$ and $070^{\circ}$. The accuracy of the orientations was checked by locating several ridges on topographic maps and measuring their orientations.

Field observations of the character of the ridge materials provide the basis for interpreting the ridges as large dunes. Although good exposures of the deposits are not common, where they occur the stratigraphy consists of two facies. The lower facies is clean, pebble-free sand that locally is more than $20 \mathrm{~m}$ thick and that in places exhibits large-scale, highangle cross-stratification (Fig. 2b). A Bison metacarpal (7) was collected from this facies, indicating that the deposits are nonmarine and no older than Pleistocene $(8)$. The upper facies is 4 to $10 \mathrm{~m}$ of sand that in places contains Salix (willow) shrubs in growth position in the lower few meters and commonly includes a peaty paleosol in the upper $3 \mathrm{~m}$
(9). The small longitudinal and parabolic dunes (2) are part of the upper facies and generally overlie the paleosol. The contact between the two units appears to be a buried replica of the modern gently rolling surface.

Bedding attitudes in separate sets of large-scale cross-strata measured at widely separated sites in the lower facies are remarkably consistent (Fig. 1c). All dips except one are to the northwest or southwest. A line bisecting the azimuths that enclose the plotted dips trends $079^{\circ}$, which is close to the dominant ridge trend. Dips in 8 of the 18 measurements are from $24^{\circ}$ to $30^{\circ}$. These steeply dipping laminae are in sets from 1 to $10 \mathrm{~m}$ thick and are interpreted as dune slipface deposits. The attitudes indicate westerly sand movement and are explainable in terms of net sand transport parallel to the ridge axes.

The presence of high-angle cross-stratification with consistent westerly dips, absence of pebbles, absence of beds of silt- or clay-sized materials, absence of marine fossils, and presence of terrestrial mammalian fossils, peat beds, and buried wood in growth position indicate that the ridges do not consist of marine sand as previously supposed (5). Rather, they consist of eolian sand composed of an older, largely vegetation-free facies deposited during a time when large dunes with at least locally well developed slip faces were active and a thinner, younger facies that contains woody zones and peat beds and lacks evidence for large slip faces. Eight radiocarbon dates on wood from the lower part of the younger facies range from $11,400 \pm 160$ to $9,640 \pm 150$ years ago. Sand of the older facies is therefore Pleistocene in age.

The ridge and thermokarst-basin terrain probably consists of the subdued remnants of the dunes of an essentially vegetation-free Pleistocene sand sea that have been blanketed by Holocene and latest Wisconsinan eolian sand, covered by tundra vegetation, and extensively modified by thermokarst processes as the modern thaw lakes formed. Growth of the sand sea created a topographic high, initiated aggradation by some streams entering the area of the dunes, and deflected Price River and Key Creek westward. Because sedimentary structures in the large dunes indicate westerly sand transport, the source is believed to be Pleistocene marine and alluvial sand east of the sand sea.

Slip faces that would have facilitated the classification of dune type in the sand sea have been obliterated. However, because the ridges are symmetrical and the bedding attitudes are compatible with sand transport parallel to the ridges rather than across them, the large dunes are interpreted as linear or longitudinal dunes $(I)$.

Comparison of the orientation of the large dunes to the modern wind system suggests an interpretation of the paleowinds responsible for formation of the sand sea. Modern blowouts in the ridge terrain, which define the modern sandmoving winds, are elongate parallel to the ENE-WSW ridge trends shown in Fig. $1 \mathrm{~b}$ and are most common on eastfacing bluffs. The small stabilized parabolic and longitudinal dunes described by Black (2) are also parallel to the ridge trends and indicate westerly sand transport, showing that the sand-moving winds of the Holocene were similar to those of today. In addition, the weak NNW-SSE elongation of oriented lakes (Fig. 1b) determined for this part of the coastal plain by Sellmann et al. (10) is similar to preferred orientations throughout the coastal plain. Because lake elongation is the result of wind-induced erosional processes that lead to elongation perpendicular to the prevailing winds (11), wind directions across the ridge terrain clearly are representative of the regional winds and are not controlled by local topography. Ridge trends are roughly perpendicular to lake elongation and are therefore parallel to the dominant regional winds. Although the relation between wind regime and linear dunes is controversial ( $(1)$ and complex (12), parallelism between most large 
dune ridges and the modern prevailing winds and between the directions of present and past sand movement suggest that the sand sea may have formed in a wind regime similar to the modern regime, in which a major component is a strong ENE wind.

Recognition of the large dunes allows reinterpretation of linear and curvilinear trends identified previously in Landsat summer scenes of the sand sea area and ascribed to bedrock structural control (4, 13). The trends reported were a NE-SW to ENE-WSW linear trend, a nearly orthogonal NW-SE linear trend, and elliptical or crescentic trends and were identified on the basis of lake alignments, lake shape, and lake-free areas and by means of a texture analyzer. The trends are reinterpreted here in terms of the morphology of the sand sea and the subsequent development of thermokarst lakes. The NE-SW to ENE-WSW trends are determined by dune ridges and chains of thermokarst lakes in interdune troughs, the elliptical or crescentic trends occur where chains of lakes enclose dune ridges or the nose of a ridge, and the NW-SE trends are a result of lake elongation perpendicular to the prevailing winds.

This stabilized sand sea is the most extensive field of large dunes yet reported in the North American Arctic. At the sand sea's eastern edge, eolian sand overlies Quaternary alluvial and marine deposits; at its southern edge, $20 \mathrm{~m}$ of eolian sand overlies at least $15 \mathrm{~m}$ of alluvial sand and silt. East of Teshekpuk Lake, the linear northern margin of the large dunes is oblique to the dominant ridge trend. Because marine deposits are common at or near the surface to the north, this boundary may be an ancient shoreline.

The age of inception and periods of activity of the sand sea are uncertain, but Late Wisconsinan seems the most reasonable age assignment for the latest episode of activity. Further study of the eolian sand and the adjacent and subjacent deposits should provide more precise dating, will improve our understanding of Pleistocene paleoclimate and paleoecology of the Arctic Coastal Plain, and will yield additional information on the distinctive sedimentary structures of eolian deposits formed in cold climates (14). Knowledge of the history of eolian activity is desirable for an assessment of the sensitivity of the environment to human activity in the National Petroleum Reserve in Alaska.

U.S. Geological Survey,

L. David Carter

Menlo Park, California 94025

SCIENCE, VOL. 211, 23 JANUARY 1981

\section{References and Notes}

1. E. D. McKee, U.S. Geol. Surv. Prof. Pap. 1052 (1979), pp. 1 and 82

2. R. F. Black, Arctic 4, 89 (1951).

3. L. W. Gatto and D. M. Anderson, Science $\mathbf{1 8 8}$ 255 (i975)

4. W. A. Fischer and E. H. Lathram, Oil Gas J. 71 97 (1973); E. H. Lathram, 1. L. Tailleur, W. W. Patton, Jr., W. A. Fischer, in Symposium on Significant Results Obtained from Earth Resources Technology Satellite 1, vol, 2, Summary of Results, S. C. Freden, E. P. Mercanti, D. E. Witten, Eds. (NASA, Greenbelt, Md., 1973), p. 31 .

5. R. F Black, U.S Geol. Surv, Prof. Pap. 302-C (1964), p. 59; J. B. O'Sullivan, thesis, Iowa State University of Science and Technology, Ames University

6. Refer to the U.S. Geological Survey 1:63,360 series topographic maps of the following quadran gles: Teshekpuk (A-1) through (A-3) and (B-1 through (B-3); Harrison Bay (A-5) and (B-3) through (B-5); and Umiat (D-4) and (D-5). See also the U.S. Geological Survey 1:250,000 series topographic map of the Ikpikpuk River quadrangle.
7. Identified by C. R. Repenning (personal communication)

8. A. V. Sher, Int. Geol. Rev. 16, 1 (1974)

9. L. D. Carter and S. W. Robinson, U.S. Geol. Surv. Open-File Rep. 78-320 (1978); American Ouaternary Association Abstracts of the Fifth Biennial Meeting (1978), p. 192

10. P. V. Sellmann, J. Brown, R. I. Lewellen, H. McKim, C. Merry, U.S. Army Corps Eng: Cold Reg. Res. Eng. Lab. Res. Rep. 344 (1975).

11. C. E. Carson and K. M. Hussey, J. Geol. 70, 417 (1962)

12. S. G. Fryberger, U.S. Geol. Surv. Prof. Pap. $1052(1979)$, p. 137

13. A. F. Maurin and E. H. Lathram, U.S. Geol. Surv. Prof. Pap. 1015 (1977), p. 213

14. T. S. Ahlbrandt and S. Andrews, Palaeogeogr. Palaeoclimatol. Palaeoecol. 25, 327 (1978).

15. I thank L. W. Gatto for supplying the Landsat image used in this report and $P$. V. Sellmann for permitting reproduction of the lake elongation data. I also thank D. M. Hopkins and J. R. Williams for reviewing the manuscript and J. P. Galloway and M. P. Springer for assisting in the field.

21 July 1980; revised 4 November 1980 